\title{
Chronic Hepatitis $C$ treatment for genotype 2 or 3 in Brazil: cost effectiveness analysis of peginterferon plus ribavirin as first choice treatment
}

\author{
Carine Raquel Blatt ${ }^{1,2,3, *}$, Bernd Storb ${ }^{1,2}$, Nikolai Mühlberger ${ }^{2,4}$, Mareni Rocha Farias $^{1,2}$, \\ Uwe Siebert ${ }^{2,4,5}$
}

\begin{abstract}
${ }^{1}$ Departament Pharmaceutical Science, Federal University of Santa Catarina, Florianópolis, SC, Brazil, ${ }^{2}$ Departament Public Health, Hall, Austria, ${ }^{3}$ Federal University of Health Science from Porto Alegre, Porto Alegre, Brazil, ${ }^{4}$ Oncotyrol, Innsbruck, Austria, ${ }^{5}$ Departament HPM \& MGH-ITA, Harvard University, Boston, United States of America
\end{abstract}

\begin{abstract}
Brazilian Guidelines to HCV treatment (2007) recommended that the first choice treatment for patients with chronic hepatitis $\mathrm{C}(\mathrm{CHC})$ and genotype 2 or 3 is interferon alpha (IFN) plus ribavirin (RBV) for 24 weeks. The aim of this study is compare the cost and effectiveness to Hepatitis $\mathrm{C}$ treatment in patients with genotype 2 or 3 of peginterferon alpha (PEG) as the first choice of treatment within PEG for those that do not respond to IFN. The target population is CHC patients with genotype 2 or 3 in Brazil. The interventions are: PEG-SEC (first IFN plus RBV for 24 weeks, after, for non-responders and relapsers subsequently PEG plus RBV for 48 weeks); PEG-FIRST24 (PEG+RBV for 24 weeks). The type of the study is cost-effectiveness analysis. The data sources are: Effectiveness data from meta-analysis conducted on the Brazilian population. Treatment cost from Brazilian micro costing study is converted into USD (2010). The perspective is the Public Health System. The outcome measurements are Sustained Viral Response (SVR) and costs. PEG-FIRST24 (SVR: 87.8\%, costs: USD 8,338.27) was more effective and more costly than PEG-SEC (SVR: 79.2\%, costs: USD 5,852.99). The sensitivity analyses are: When SVR rates with IFN was less than $30 \%$ PEG-FIRST is dominant. On the other hand, when SVR with IFN was more then $75 \%$ PEG-SEC is dominant (SVR=88.2\% and costs USD \$ 3,753.00). PEG-SEC is also dominant when SVR to PEG24 weeks was less than 54\%. In the Brazilian context, PEG-FIRST is more effective and more expensive than PEG-SEC. PEG-SEC could be dominant when rates of IFN therapy are higher than $75 \%$ or rates of PEG 24 therapy are lower than $54 \%$.
\end{abstract}

Uniterms: Hepatitis $\mathrm{C}$ chronic/treatment. Interferon alpha/Hepatitis $\mathrm{C}$ treatment. Ribavirin/Hepatitis $\mathrm{C}$ treatment. Peginterferon alpha/Hepatitis $\mathrm{C}$ treatment. Hepatitis $\mathrm{C} /$ treatment/cost-effectiveness evaluation.

O protocolo brasileiro de tratamento da Hepatite C (2007) recomendava como primeira escolha para pacientes com hepatite $\mathrm{C}$ crônica e portadores de genótipo 2 ou 3 o tratamento com interferona alfa (IFN) associada à ribavirina (RBV), por 24 semanas. O objetivo deste estudo é comparar o custo e a efetividade para pacientes com hepatite $\mathrm{C}$ crônica e portadores do genótipo 2 ou 3 o uso de peguinterferon (PEG) como primeiro escolha com o PEG como secunda escolha para aqueles que não responderam ao tratamento com IFN. A população alvo compreende pacientes com hepatite $\mathrm{C}$ crônica portadores de genótipo 2 ou 3 no Brasil. As intervenções são: PEG-SEC (IFN + RBV por 24 semanas, para os não respondedores e recidivantes tratamento subsequente com PEG + RBV por 48 semanas; PEG-FIRST24 (PEG + RBV por 24 semanas). O tipo de estudo envolvido é Análise de Custo Efetividade. Os dados de efetividade são provenientes de um metanálise de estudos brasileiros e os dados de custo do tratamento de um estudo de custo do contexto brasileiro. A perspectiva é o Sistema Público de Saúde. Os desfechos avaliados foram Resposta Viral Sustentada (RVS) e Custos. PEG-FIRST24 (RVS: 87,8\%, costs: USD 8.338,27) foi mais efetivo e apresentou maior custo que PEG-SEC (RVS: 79,2\%, custo USD 5.852,99).

\footnotetext{
*Correspondence: Carine Raquel Blatt. Departamento de Farmacociências, Universidade Federal de Ciências da Saúde de Porto Alegre. Rua Sarmento Leite, 245, 90050-170 - Porto Alegre - RS, Brasil. E-mail: carine.blatt@gmail.br
} 
A análise de sensibilidade demonstrou que PEG-SEC é dominado por PEG-FIRST24 quando RVS com IFN for menor que $30 \%$. Por outro lado, quando RVS com IFN for maior que $75 \%$ PEG-SEC é dominante (RVS $=88.2 \%$ e custo USD \$ 3.753,00). PEG-SEC é também dominante quando RVS para PEG24 for menor que 54\%. Conclusão: No contexto brasileiro, PEG-FIRST é mais efetivo e mais custoso que PEG-SEC. PEG-SEC poderia ser dominante quando as taxas de RVS do tratamento com IFN forem superiores a $75 \%$ ou as taxas de PEG24 forem inferiores a $54 \%$.

Unitermos: Hepatite C crônica/tratamento. Interferona alfa/tratamento da hepatite C. Ribavirin/ tratamento da hepatite C. Peginterferona alfa/tratamento da hepatite C. Hepatitis C/tratamento/análise de custo-efetividade.

\section{INTRODUCTION}

The prevalence of Chronic Hepatitis C (CHC) varies widely, depending on geographic region and exposure to secondary risk factors. In Brazil the prevalence was estimated at $2.5 \%$ among adults. Most of the prevalence studies focused on specific subsets of the population, which could not be used for extrapolative purposes (Kershenobich et al., 2011). The Brazilian Ministry of Health is carrying out a population-based survey to provide information on the prevalence of hepatitis viral infections, where the pattern of risk factors was considered in the urban population of all Brazilian state capitals and the Federal District, between 2005 and 2009 (Ximenes et $a l ., 2010)$. Preliminary data suggests that the prevalence of hepatitis $\mathrm{C}$ ranges from $0.9 \%$ to $1.9 \%$ (Brazil, 2010).

A Brazilian study assessed 1,688 HCV patients from multiple regions and reported the following genotype distribution: genotype $1(64.9 \%)$, genotype $2(4.6 \%)$, genotype $3(30.2 \%)$ and genotype $4(0.2 \%)$ (Campiotto et al., 2005).

Progression to chronic hepatitis $\mathrm{C}$ occurs in at least $80 \%$ of patients with acute HCV infection, and cirrhosis develops in $20-30 \%$ of these individuals (Shepherd et al., 2007). The evolution of the illness is associated with the development of cirrhosis, liver insufficiency or hepatocellular carcinoma, the leading cause of liver transplantation in adults (Seeff, 2009).

According to a national survey to update hepatocellular carcinoma epidemiology in Brazil, encompassing 29 centers and 1,405 patients and carried out from 2004 to 2009 , hepatitis C infection was found to be the most common etiology of liver cirrhosis and liver cirrhosis was the main risk factor for HCC development in Brazil (Carrilho et al., 2010). The management of $\mathrm{HCV}$ infection is one of the most important current health concerns because of the high risk of chronic infection and the lack of a suitable vaccine.

In beginning of $\mathrm{HCV}$ treatment the most effective initial therapy for patients with hepatitis $C$ was the combination of interferon alpha (IFN) with ribavirin (RBV) (Poynard et al., 1998; Mchutchison, 1999). Recently, there has been a modification of interferon alpha with the addition of a polyethylene glycol molecule to interferon (PEG) in order to produce a biologically active molecule with a longer half-life than the natural molecule. More favorable pharmacokinetics and its characteristics allow for weekly dose administration which is more convenient (Manns et al., 2001).

The results from clinical trials indicate that $\mathrm{HCV}$ genotype 1 have better rates of sustained viral response (SVR) using peginterferon alpha (PEG) plus RBV compared to IFN plus RBV (SVR for PEG alpha-2a combination therapy were $46 \%$, compared with $36 \%$ for interferon alpha-2a combination therapy). But for genotype 2 or 3 the rates of SVR do not have statistical significance in either treatment. When the PEG alpha-2b and interferon alpha- $2 \mathrm{~b}$ combination therapies were compared, the SVR values were $82 \%$ and $79 \%$ respectively, on an intentionto-treat basis (Manns et al., 2001; Nice, 2004; Shepherd et al., 2007; Nice, 2010).

In many countries like the United Kingdom, Austria, Canada and Sweden, regardless of genotype, the preferred treatment regimen is a combination of PEG $2 \mathrm{a}$ or $2 \mathrm{~b}$, administered subcutaneously once a week, with RBV taken orally daily in two doses. The duration of treatment depends on the hepatitis $\mathrm{C}$ virus genotype. For HCV genotype 1 or 4 , patients should be treated for 48 weeks. For HCV genotype 2 or 3, treatment duration is 24 weeks (Sherman et al., 2007; Lagging et al., 2009; Maieron et al., 2010; Nice, 2010).

In the German context, to prevent one clinical event such as progression to cirrhosis, descompensated cirrhosis, hepatocellular carcinoma, liver transplantation and death due to liver failure during 20 years, the numbers needed to treat were approximately 3 for IFN plus RBV and 2 for PEG plus RBV, when compared with no antiviral therapy. Compared to no antiviral therapy, IFN plus RBV saved 2.9 life years, and PEG plus RBV saved 4.6 life years (Siebert et al., 2005). 
Differences in countries' sociodemographic structure, distribution of patients' clinical characteristics, patients' preferences, resource utilization and prices make it difficult, if not impossible, to transfer the results from other health care systems to the Brazilian reality (Siebert et al., 2003; Vanni et al., 2009).

The combination therapy with PEG is more expensive than IFN (Siebert et al., 2003). The use of PEG in the replacement of IFN is limited due to its high cost. In Brazil, the option has been to limit the use of this medicine to subjects with genotype 1 or co-infection with HIV(Brasil, 2007).

The aim of this study is to compare the cost and effectiveness for patients with genotype 2 or 3 of PEG as the first choice of treatment with what is suggested in the Brazilian guidelines.

\section{METHODS}

We developed a decision analysis Markov model to examine the cost and effectiveness of chronic hepatitis $\mathrm{C}$ treatment in patients with genotype 2 or 3 from a public health system perspective in Brazil.

The Brazilian guidelines recommend to patients with genotype 2 or 3 without cirrhosis (F4) or F3 Metavir score the use of IFN plus RBV for 24 weeks and, subsequently for non-responders and relapsers, PEG plus RBV for 48 weeks (PEG-SEC). We compared this course of treatment with the use of PEG as a first choice of treatment for 24 weeks (PEG-FIRST24).

The SVR rates were taken from meta-analysis conducted on the Brazilian population and according to the group undergoing treatment (Blatt, 2011).

The cost data were from a Brazilian micro costing study from a public health perspective. The costs include treatment cost for antiviral drugs, secondary medicines, diagnostic tests, outpatient visits to physicians and other professionals, hospitalizations, nursing and pharmaceutical care (Blatt, 2011).

The outcome measures were SVR, direct costs and incremental cost effectiveness ratio (ICER). The costeffectiveness analysis compares the costs and clinical outcomes. The ICER represents the additional cost and effectiveness obtained, when one alternative is more effective and also more expensive.

The role of the sensitivity analysis is to test the variation of SVR and costs. The decision model was done using TreeAge Pro 2011 software.

\section{RESULTS}

A systematic review of eight Brazilian studies evaluated 486 non-HIV naïve patients with HCV genotype 2 or 3 who underwent treatment with IFN plus RBV for 24 weeks. The pooled response rate was $54.3 \%$ (95\% CI 39.3-69.3) (Blatt, 2011).

Patients who were genotype 2 or 3, without HIV, who underwent treatment with PEG plus RBV for 48 weeks were the focus of two studies $(n=81)$ and the pooled response rate was $73.2 \%(95 \% \mathrm{CI} 63.6-82.8)$. The relapsed patients who were genotype 2 or 3 had a pooled response rate $(\mathrm{n}=17)$ of $59.0 \%$ (95\% CI 32.9-85.1). Among nonresponder patients who were genotype 2 or $3(n=79)$ the response rate was 50.2\% (95\% CI 33.4-67.0) (Blatt, 2011).

The total direct costs of hepatitis $\mathrm{C}$ treatment with IFN plus RBV is USD \$ 982.25, with PEG 2a $180 \mu \mathrm{g}$ plus RBV is USD \$ $10,658.08$ and with PEG $2 b 120 \mu \mathrm{g}$ plus RBV is USD \$12,597.63. Antiviral drugs are the most expensive category of the cost of treatment, accounting for more than $40 \%$ of medical costs for IFN therapy and more than $88 \%$ for PEG therapy (Blatt, 2011).

The costs and effectiveness per course of treatment are included in our cost effectiveness analysis shown in Table I.

Model building for cost effectiveness analyses are shown in Figure 1. According to Brazilian data and from a public health perspective, with SVR of $87.8 \%$ and costs of USD \$ 8,338.27, PEG-FIRST was more efective and more costly than PEG-SEC (SVR: 79.2\%, costs: USD 5,852.99).

In the sensitivity analysis, for PEG-SEC dominates PEG-FIRST24 when SVR with IFN was less than 30\%. On the other hand, when SVR with IFN was more then $75 \%$, PEG-SEC is dominant $(\mathrm{SVR}=88.2 \%$ and costs USD $\$ 3,753.00)$. PEG-SEC is also dominant when SVR to

TABLE I - Costs (USD \$) and effectiveness per course of treatment

\begin{tabular}{lcc}
\hline Group & Costs & SVR (\%) \\
\hline Naive IFN + RBV 24 weeks & 982.25 & 54.3 \\
Naive PEG + RBV 24 weeks & 5481.90 & 73.2 \\
Relapser and nonreponder (IFN) + PEG + RBV 48 weeks & $982.25+10,658.08$ & 54.6 \\
Relapser and nonreponder (PEG24) + PEG + RBV 48 weeks & $5481.90+10,658.08$ & 54.6 \\
\hline
\end{tabular}




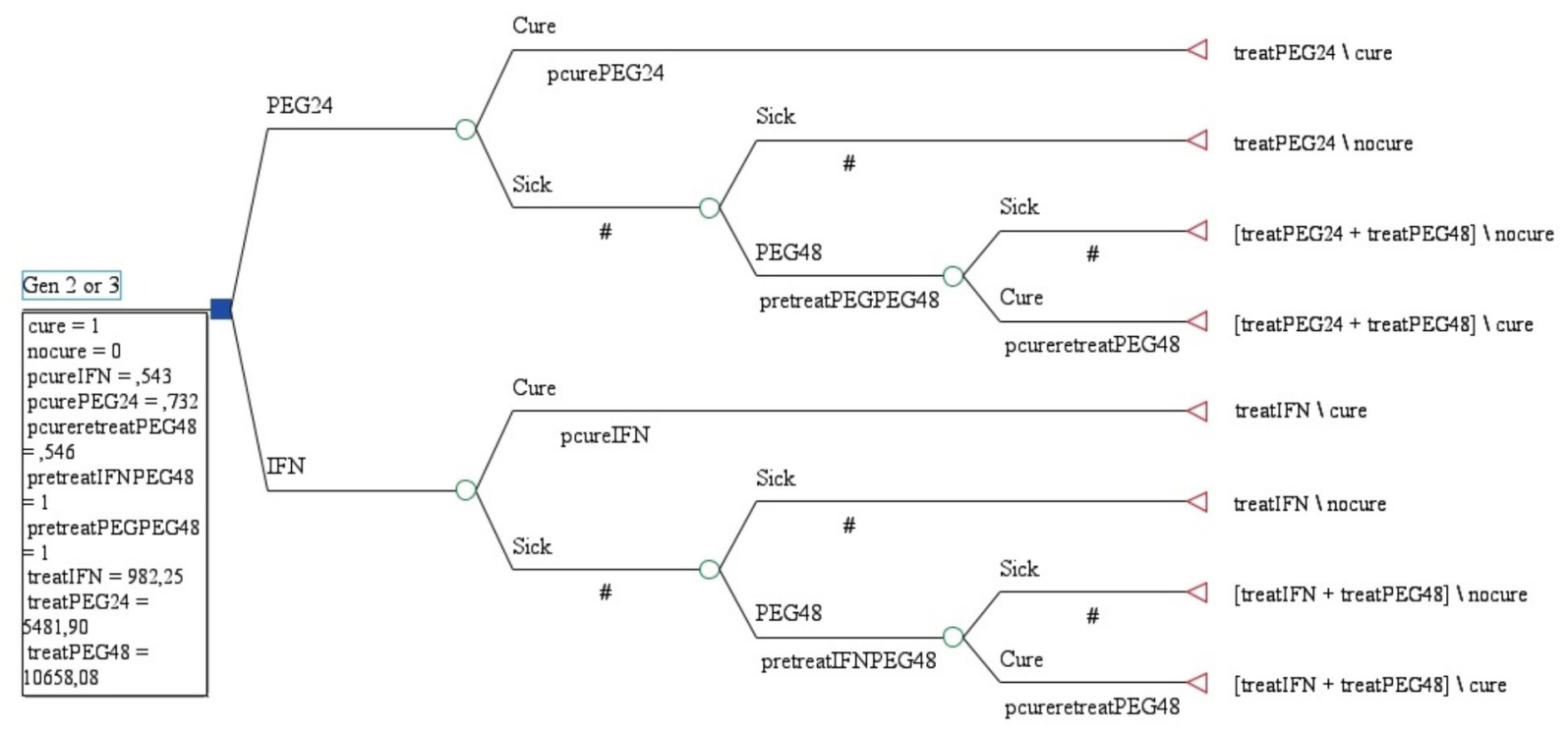

FIGURE 1 - Cost effectiveness analysis comparing PEG-SEC with PEG-FIRST24.

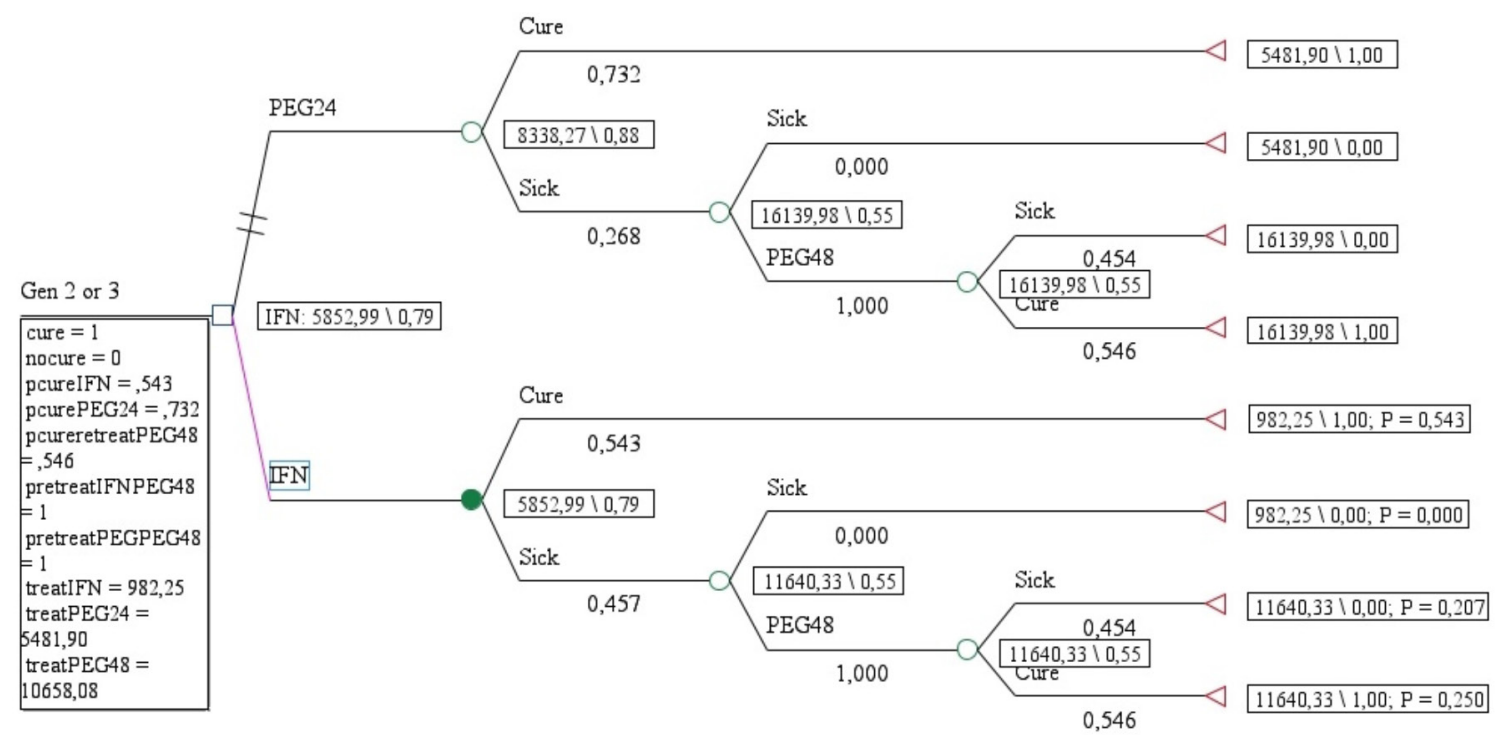

FIGURE 2 - Results of cost effectiveness analysis comparing PEG-SEC with PEG-FIRST24.

PEG24 weeks was less than 54\%. ICER for PEG-FIRST24 is USD \$28,963.86 per additional SVR.

\section{DISCUSSION}

Hepatitis $\mathrm{C}$ treatment has the potential to prevent clinical events such as progression to cirrhosis, decompensated cirrhosis, hepatocellular carcinoma, liver transplantation and death due to liver failure. Therefore, the use of best practice could prevent side effects and waste of resources.

The most common side effects with a combination of PEG and RBV include injection site reactions, influenza-like symptoms (fatigue, headache, fever, rigors, and myalgia), psychiatric side effects (depression, irritability, anxiety and insomnia), nausea, alopecia, skin reactions (rash, pruritis and dry skin), plaquetopenia, neutropenia and anemia. This side effect profile often makes therapy difficult to tolerate and sometimes requires dose modifications and/or additional medical treatments (Fried, 2002; Mchutchison, Manns, Longo, 2006; Mchutchinson et al., 2007).

Severe side effects may occur more frequently in patients treated with PEG plus RBV than in patients treated with IFN plus RBV (Manns et al., 2001; Fried et al., 2002). From this point of view the best choice is PEG-SEC. 
However, if SVR rates to IFN are lower, a great number of patients will undergo re-treatment with PEG.

Re-treatment with PEG plus RBV may be offered to people whose hepatitis $\mathrm{C}$ has not shown an adequate response to treatment (non-response) or has responded but subsequently relapsed. On the other hand, for patients who were not successful with IFN to undergo a new course of treatment could decrease the quality of their lives and expose them to side effects again.

In clinical trials, as mentioned above, when PEG alfa- $2 b$ and IFN alfa-2b combination therapies were compared for patients with genotype 2 or 3, SVR don't have statistical difference significant (Manns, Mchutchison et al., 2001). In a meta-analysis of real life Brazilian studies the values were similar to PEG and smaller to IFN (Blatt, 2011) respectively.

SVR rates in individual studies in Brasil to Non-HIV naïve patients with $\mathrm{HCV}$ genotype 2 or 3 who underwent treatment with IFN plus RBV for 24 weeks varied from $33 \%$ to $80 \%$ (Alves, De Azevedo et al., 2003; Acras, Pedroso et al., 2004; Borges, 2004; Villela-Nogueira, Perez et al., 2005; Parise, De Oliveira et al., 2006; Fachini, 2008; Almeida et al., 2009; Carneiro et al., 2010; Vigani et al., 2012). SVR rates from this Brazilian studies are very different from each other and below the main clinical trials found in literature (Manns et al., 2001). In this respect, it is important to emphasize that this is a follow-up study of patients treated in a real life scenario of Brazilian public health system, reflecting the reality of our health care system and regions differences. Also, patients are different from the reality of a clinical trial where the inclusion criteria are extremely strict and approach to patient is done differently.

These data showed that in real life in Brazil SVR to IFN therapy was lower in comparison to clinical trials. One possible reason for this is that according to current Brazilian guidelines PEG is administered once a week, in specialized centers, so the vials that should be stored at $2-8{ }^{\circ} \mathrm{C}$ have been stored in an appropriate environment under pharmaceutical supervision. However, the IFN vials, which are administered three times a week, are stored in patients' houses without temperature control.

In other hand, since 2000, biosimilar standard IFN has been used in Brazil for genotypes 2 or 3 infections. Biosimilar Peg-IFN is not available, the only Peg- IFN formulations currently available are Peg- ifn alpha-2a (Pegasys ${ }^{\circledR}$ ) or alpha-2b (Peg i ntron $\left.{ }^{\circledR}\right)$. Therefore, the Peg- IFN used in this study are the same formulations used in studies reported in the literature (Vigani, 2012). Therefore, this authors suggests that biosimilar IFN in Brasil have less effectiveness than the main clinical trials found in literature.
In addition to the issue of storage, and despite lower rates of SVR to IFN therapy, patients that are followed up in specialized centers probably have more chance of concluding treatment compared to patients who took medicines at home.

PEG-FIRST24 has a convenient dosage schedule compared to IFN therapy (once a week rather than three times a week). Moreover, discontinuation of treatment is most common in patients who received treatment for 48 weeks compared to those who received treatment for 24 weeks (Shepherd et al., 2004). In patients infected with HCV genotype 2 or 3 the rates of SVR achieved after 24 weeks of treatment were not increased by prolonging treatment for a further 24 weeks (Nice, 2010), therefore, treatment with PEG-FIRST24 has the same SVR and is less costly. Effective patient education and drug therapy management are essential in enabling patients to adhere to the treatment regimen, which lasts for either 24 or 48 weeks. Frequent monitoring of patients and, often, adjustments in the dosage of one or both components of the therapy are necessary during the course of treatment (Olson, Lentz, 2009).

This study has some limitations, firstly in Brazil the SVR rates can be different according to service organization and secondly we assume that $100 \%$ who failed the first treatment will undergo the second treatment.

Therefore, study done with Brazilian population suggest that subjects with chronic hepatitis due to HCV genotypes 2 or 3 and who have a low degree of fibrosis are ideal candidates for treatment with IFN plus RBV. On the other hand, patients with advanced stage fibrosis had low rates of response to this combined therapy, and a criterion of treatment with pegylated interferon as a first alternative should be considered (Parise et al., 2006). Despite this considerations we don't do sub analysis considering the degree of hepatic fibrosis.

\section{CONCLUSION}

In the Brazilian context, PEG-FIRST24 is more effective and more costly than PEG-SEC. Start to therapy with IFN could be dominant only when rates of IFN therapy are higher than $75 \%$ or when rates of PEG24 therapy are lower than $54 \%$. For this option of treatment monitored the biosimilar IFN effectiviness are very important.

Effectiveness or cost-effectiveness cannot be automatically inferred from these results without additional decision analyses. Regardless of the antiviral therapy chosen we need to improve the patient care on treatment. Improve the IFN effectiveness could be a good option for better results to hepatitis $\mathrm{C}$ treatment. 
Considering the lower rates of successful treatment with IFN from Brazilian studies the results suggest more effetivenes with PEG treatment to non-HIV naïve patients with HCV genotype 2 or 3, however PEG have incremental costs when compare with IFN.

\section{REFERENCES}

ACRAS, R.N.; PEDROSO, M.L.A.; CAUM, L.C.; PISANI, J.C.; AMARANTE, H.M.B.S.; CARMES, E.R. The sustained response rates for chronic hepatitis $\mathrm{C}$ patients undergoing therapy with the several interferons and ribavarins supplied by Brazilians Health Ministry is comparable to those reported in the literature. Arq. Gastroenterol., v.41, n.1, p.3-9, 2004.

ALMEIDA, A.J.; CAMPOS-DE-MAGALHÃES, M.; BRANDÃO-MELLO, C.E.; OLIVEIRA, R.V.; ESPIRITOSANTO, M.P.; YOSHIDA, C.F.; LAMPE, E. Detection of hepatitis $\mathrm{C}$ virus in platelets: evaluating its relationship to antiviral therapy outcome. Hepatogastroenterology, v.56, n.90, p.429-436, 2009.

ALVES, A.V.; AZEVEDO, A.P.C.; PERIN, C.; RAMOS, G.Z.; BRANDÃO, A.B.M.; MATTOS, A.A.; ALMEIDA, P.R.L. Interferon-alpha and ribavirin therapy on chronic hepatitis $\mathrm{C}$ virus infection: the experience of Rio Grande do Sul State Health Department, Brazil. Arq. Gastroenterol., v.40, n.4, p.227-232, 2003.

BLATT, C.R. Um olhar sobre a efetividade e custos do tratamento da hepatite $C$ sob a perspectiva do Sistema Único de Saúde. Florianópolis, 2011. 190 f. [Thesis of PhD degree. Faculty of Pharmaceutical Sciences, Federal University of Santa Catarina].

BORGES, S.C. Influência do polimorfismo do gente HFE na resposta sustentada a interferon + ribavirina em pacientes com infecção crônica pelo genótipo 2 ou 3 do vírus da hepatite $\mathrm{C}$ e ferritina sérica elevada. Porto Alegre, 2004. $2222 \mathrm{f}$. [Thesis of PhD degree. Federal University of Rio Grande do Sul].

BRASIL. Hepatites virais em números. v.2010. n.28/07/2010. Brasília: Health Ministry. Health Surveillance Secretary, 2010.

BRASIL. Portaria $\mathrm{n}^{\circ}$ 34, de 28 de setembro de 2007. Aprova o Protocolo Clínico e Diretrizes Terapêuticas - hepatite viral C. v.34. Brasília: 28 Sept. 2007.
CAMPIOTTO, S.; PINHO, J.R.; CARRILHO, F.J.; DA SILVA, L.C.; SOUTO, F.J.; SPINELLI, V.; PEREIRA, L.M.; COELHO, H.S.; SILVA, A.O.; FONSECA, J.C.; ROSA, H.; LACET, C.M.; BERNARDINI, A.P. Geographic distribution of hepatitis $\mathrm{C}$ virus genotypes in Brazil. Braz. J. Med. Biol. Res., v.38, n.1, p.41-49, 2005.

CARNEIRO, V.L.; LEMAIRE, D.C.; BENDICHO, M.T.; SOUZA, S.L.; CAVALCANTE, L.N.; ANGELO, A.L.; FREIRE, S.M.; MENDES, C.M.; SANTANA, N.; LYRA, L.G.; LYRA, A.C. Natural killer cell receptor and HLA-C gene polymorphisms among patients with hepatitis $\mathrm{C}$ : a comparison between sustained virological responders and non-responders. Liver Int., v.30, n.4, p.567-573, 2010.

CARRILHO, F.J.; KIKUCHI, L.; BRANCO, F.; GONCALVES, C.S.; MATTOS, A.A. Brazilian HCC Study Group. Clinical and epidemiological aspects of hepatocellular carcinoma in Brazil. Clinics, v.65, n.12, p.1285-1290, 2010.

FACHINI, R.M. Estudo epidemiológico das vias de transmissão do vírus da hepatite $\mathrm{C}$ e resposta ao tratamento segundo a genotipagem. São José do Rio Preto, 2008. 197 f. [Thesis of PhD degree. Department of Health Sciences. Faculty of Medcine of São José do Rio Preto].

FRIED, M.W. Side effects of therapy of hepatitis $\mathrm{C}$ and their management. Hepatology, v.36, n.5, suppl.1, p.S237-S244, 2002.

FRIED, M.W.; SHIFFMAN, M.L.; REDDY, K.R.; SMITH, C.; MARINOS, G.; GONÇALES JR, F.L.; HÄUSSINGER, D.; DIAGO, M.; CAROSI, G.; DHUMEAUX, D.; CRAXI, A.; LIN, A.; HOFFMAN, J.; YU, J. Peginterferon alfa-2a plus ribavirin for chronic hepatitis $\mathrm{C}$ virus infection. N. Engl. J. Med., v.347, n.13, p.975-982, 2002.

KERSHENOBICH, D.; RAZAVI, H.A.; SÁNCHEZ-AVILA, J.F.; BESSONE, F.; COELHO, H.S.; DAGHER, L.; GONÇALES, F.L.; QUIROZ, J.F.; RODRIGUEZ-PEREZ, F.; ROSADO, B.; WALLACE, C.; NEGRO, F.; SILVA, M. Trends and projections of hepatitis $\mathrm{C}$ virus epidemiology in Latin America. Liver Int., v.31, suppl.2, p.18-29, 2011.

LAGGING, M.; WEJSTÅL, R.; UHNOO, I.; GERDÉN, B.; FISCHLER, B.; FRIMAN, S.; JOSEPHSON, F.; KARLSTRÖM, O.; SANGFELT, P.; SCHVARZ, R.; WEILAND, O.; SWEDISH CONSENSUS GROUP. Treatment of hepatitis $\mathrm{C}$ virus infection: updated Swedish Consensus recommendations. Scand. J. Infect. Dis., v.41, n.6-7, p.389-402, 2009. 
MAIERON, A.;METZ-GERCEK, S.; HACKL, F.; ZIACHEHABI, A.; FUCHSTEINER, H.; LUGER, C.; MITTERMAYER, H.; SCHÖFL, R. Antiviral treatment of chronic hepatitis $\mathrm{C}$ in clinical routine. Wien. Klin. Wochenschr., v.122, n.7-8, p.237-242, 2010.

MANNS, M.P.; MCHUTCHISON, J.G.; GORDON, S.C.; RUSTGI, V.K.; SHIFFMAN, M.; REINDOLLAR, R.; GOODMAN, Z.D.; KOURY, K.; LING, M.; ALBRECHT, J.K. Peginterferon alfa-2b plus ribavirin compared with interferon alfa-2b plus ribavirin for initial treatment of chronic hepatitis C: a randomised trial. Lancet, v.358, n.9286, p.958-965, 2001.

MCHUTCHISON, J. Hepatitis C therapy in treatment-naive patients. Am. J. Med., v.107, n.6B, p.56S-61S, 1999.

MCHUTCHISON, J.G.; MANNS, M.P.; BROWN JR, R.S.; REDDY, K.R.; SHIFFMAN, M.L.; WONG, J.B. Strategies for managing anemia in hepatitis $\mathrm{C}$ patients undergoing antiviral therapy. Am. J. Gastroenterol., v.102, n.4, p.880889, 2007.

MCHUTCHISON, J.G.; MANNS, M.P.; LONGO, D.L. Definition and management of anemia in patients infected with hepatitis C virus. Liver Int., v.26, n.4, p.389-398, 2006.

NATIONAL Institute for Health and Care Excellence. Peginterferon alfa and ribavirin for the treatment of chronic hepatitis C. TA200. NICE technology appraisal guidance 200, p.46, 2010.

NATIONAL INSTITUTE FOR HEALTH AND CARE EXCELLENCE. Technology Appraisal Guidance. Interferon alfa (pegylated and non-pegylated) and ribavirin for the treatment for chronic hepatitis C. TA75. NICE Technology Appraisal Guidance 75, 2004. Available at: < http://www.nice.org.uk/guidance/TA75>. Accessed on:jun. 2014.

OLSON, N.; LENTZ, N. Pharmacotherapeutic management of chronic hepatitis C infection. J. Pharm. Soc. Wisconsin (verificar abreviatura), v.11/12, n.???, p.22-29, 2009.

PARISE, E.R.; DE OLIVEIRA, A.C.; CONCEIÇÃO, R.D.; AMARAL, A.C.; LEITE, K. Response to treatment with interferon-alpha and ribavirin in patients with chronic Hepatitis $\mathrm{C}$ virus genotypes 2 and 3 depends on the degree of hepatic fibrosis. Braz. J. Infect. Dis., v.10, n.2, p.78-81, 2006.
POYNARD, T.; MARCELLIN, P.; LEE, S.S.; NIEDERAU, C.; MINUK, G.S.; IDEO, G.; BAIN, V.; HEATHCOTE, J.; ZEUZEM, S.; TREPO, C.; ALBRECHT, J. Randomised trial of interferon alpha2b plus ribavirin for 48 weeks or for 24 weeks versus interferon alpha2b plus placebo for 48 weeks for treatment of chronic infection with hepatitis $C$ virus. International Hepatitis Interventional Therapy Group (IHIT). Lancet, v.352, n.9138, p.1426-1432, 1998.

SEEFF, L.B. The history of the "natural history" of hepatitis C (1968-2009). Liver Int., v.29 suppl.1, p.89-99, 2009.

SHEPHERD, J.; ACRAS, R.N.; PEDROSO, M.L.A.; CAUM, L.C.; PISANI, J.C.; AMARANTE, H.M.B.S.; CARMES, E.R. The sustained response rates for chronic hepatitis $C$ patients undergoing therapy with the several interferons and ribavarins supplied by Brazilians Health Ministry is comparable to those reported in the literature. Arq. Gastroenterol., v.41, n.1, p.3-9, 2004.

SHEPHERD, J.; BRODIN, H.; CAVE, C.; WAUGH,N.; PRICE, A.; GABBAY, J. Pegylated interferon alpha- $2 \mathrm{a}$ and $-2 \mathrm{~b}$ in combination with ribavirin in the treatment of chronic hepatitis $\mathrm{C}$ : a systematic review and economic evaluation. Health Technol. Assess., v.8, n.39, p.iii-iv, p.1-125, 2004.

SHEPHERD, J.; JONES, J.; HARTWELL, D.; DAVIDSON, P.; PRICE, A.; WAUGH, N. Interferon alpha (pegylated and non-pegylated) and ribavirin for the treatment of mild chronic hepatitis $\mathrm{C}$ : a systematic review and economic evaluation. Health Technol. Assess, v.11, n.11, p.1-205, 2007.

SHERMAN, M.; SHAFRAN, S.; BURAK, K.; DOUCETTE, K.; WONG, W.; GIRGRAH, N.; YOSHIDA, E.; RENNER, E.; WONG, P.; DESCHÊNES, M. Management of chronic hepatitis C: consensus guidelines. Can. J. Gastroenterol., v.21, suppl.C, p.25C-34C, 2007.

SIEBERT, U.; SROCZYNSKI, G.; ROSSOL, S.; WASEM, J.; RAVENS-SIEBERER, U.; KURTH, B.M.; MANNS, M.P.; MCHUTCHISON, J.G.; WONG, J.B. German Hepatitis C Model (GEHMO) Group; International Hepatitis Interventional Therapy (IHIT) Group. Cost effectiveness of peginterferon alpha- $2 b$ plus ribavirin versus interferon alpha-2b plus ribavirin for initial treatment of chronic hepatitis C. Gut., v.52, n.3, p.425-432, 2003. 
SIEBERT, U.; WASEM, J.; ROSSOL, S.; SROCZYNSKI, G.; AIDELSBURGER, P.; RAVENS-SIEBERER, U.; KURTH, B.M.; MANNS, M.P.; MCHUTCHISON, J.G.; WONG, J.B. Antiviral treatment initiation costs in chronic hepatitis C. Gut., v.54, n.1, p.172-173, 2005.

VANNI, T.; LUZ, P.M.; RIBEIRO, R.A.; NOVAES, H.M.D.; POLANCZYK, C.A. Economic evaluation in health: applications in infectious diseases. Cad. Saúde Pública, v.25, n.12, p.2543-2552, 2009.

VIGANI, A.G.; GONÇALES, E.S.; PAVAN, M.H.; GENARI, F.; TOZZO, R.; LAZARINI, M.S.; FAIS, V.; FELTRIN, A.; GONÇALES, N.S.; GONÇALES JR, F.L. Therapeutic effectiveness of biosimilar standard interferon versus pegylated interferon for chronic hepatitis $\mathrm{C}$ genotypes 2 or 3. Braz. J. Infect. Dis., v.16, n.3, p.232-236, 2012.
VILLELA-NOGUEIRA, C.A.; PEREZ, R.M.; DE SEGADAS SOARES, J.A.; COELHO, H.S. Gamma-glutamyl transferase (GGT) as an independent predictive factor of sustained virologic response in patients with hepatitis $\mathrm{C}$ treated with interferon-alpha and ribavirin. J. Clin. Gastroenterol., v.39, n.8, p.728-730, 2005.

XIMENES, R.A.A.; PEREIRA, L.M.B.; MARTELLI, C.M.T.; MERCHÁN-HAMANN, E.; STEIN, A.T.; FIGUEIREDO, G.M.; BRAGA, M.C.; MONTARROYOS, U.R.; BRASIL, L.M.; TURCHI, M.D.; FONSECA, J.C.F.; LIMA, M.L.C.; ALENCAR, L.C.A.; COSTA, M.; CORAL, G.; MOREIRA, R.C.; CARDOSO, M.R.A. Methodology of a nationwide cross-sectional survey of prevalence and epidemiological patterns of hepatitis A, B and C infection in Brazil. Cad. Saúde Pública, v.26, n.9, p.1693-704, 2010.

Received for publication on $26^{\text {th }}$ June 2012 Accepted for publication on $01^{\text {st }}$ April 2014 